\title{
Habitat specialization, distribution range size and body size drive extinction risk in carabid beetles
}

\section{Nolte, Dorothea}

2019-02

Nolte , D , Boutaud , E , Kotze , D J , Schuldt , A \& Assmann , T 2019 , ' Habitat specialization, distribution range size and body size drive extinction risk in carabid beetles ', Biodiversity and Conservation, vol. 28 , no. 5 , pp. 1267-1283 . https://doi.org/10.1007/s10531-019-01724-9

http://hdl.handle.net/10138/312115

https://doi.org/10.1007/s10531-019-01724-9

cc_by_nc_nd

acceptedVersion

Downloaded from Helda, University of Helsinki institutional repository.

This is an electronic reprint of the original article.

This reprint may differ from the original in pagination and typographic detail.

Please cite the original version. 


\title{
Habitat specialization, distribution range size and body size drive extinction risk in carabid beetles
}

Authors:

Dorothea Nolte $^{1,2}$, Estève Boutaud ${ }^{1}$, D. Johan Kotze ${ }^{3}$, Andreas Schuldt $^{4,5}$ and Thorsten Assmann ${ }^{1}$

\section{Authors affiliations:}

${ }^{1}$ Institute of Ecology, Leuphana University Lüneburg, Universitätsallee 1, 21335 Lüneburg, Germany

${ }^{2}$ Department of Biology, University of Hildesheim, Universitätsplatz 1, 31141 Hildesheim, Germany

3 Faculty of Biological and Environmental Sciences, Ecosystems and Environment Research Programme, University of Helsinki, Niemenkatu 73, Lahti, Finland

${ }^{4}$ German Centre for Integrative Biodiversity Research (iDiv) Halle-Jena-Leipzig, Deutscher Platz 5e, 04103 Leipzig, Germany

${ }^{5}$ Forest Nature Conservation, Georg-August-University Göttingen, Büsgenweg 3, 37077 Göttingen, Germany

\section{Corresponding author:}

Dorothea Nolte - e-mail: dorothea.nolte@ uni-hildesheim.de, phone: +49(0)5121 883-40706, ORCID ID: https://orcid.org/0000-0002-6605-8518

\section{Acknowledgements:}

We like to thank I. Harry, P. Brandmayr and K. Homburg for helping to complete and compile the species trait dataset, as well as two anonymous referees for their valuable comments on the manuscript.

\begin{abstract}
The worldwide biodiversity crisis is ongoing. To slow down, or even halt future species loss it is important to identify potential drivers of extinction risk. Species traits can help to understand the underlying process of extinction risk. In a comprehensive study on 464 carabid beetle species, we used
\end{abstract}


ordinal logistic regression to analyze the relationship of species traits to extinction risk in Central Europe, taking phylogenetic relatedness into account. To consider varying trait responses in different habitat types, we also tested models for species groups associated with different habitat types (forest, open, riparian and wetland). Our results identified three traits of particular importance as predictors for high extinction risk: 1) high habitat specialization, 2) small distribution range size (which is not considered in the categorization of the German Red List), and 3) large body size. Furthermore, large macropterous species showed high extinction risk. Overall, species associated with mountainous, coastal and open habitats generally revealed a high risk of extinction, while most forest species showed a low extinction risk. However, forest species with predatory feeding behavior were threatened, as were wetland species that reproduce in autumn. Phylogenetic relatedness had no influence on how species traits predict carabid beetle extinction risk. In the light of these results, management and recovery plans for species which exhibit characteristic traits strongly associated with extinction risks, as well as the conservation and restoration of mountain, coastal and open habitats, have to be prioritized.

\section{Key Words:}

Carabidae, Red List, species traits, insect decline, defaunation, conservation management 


\section{Introduction}

Biological annihilation (Ceballos et al. 2015; Ceballos et al. 2017) is a contemporary possibility, threatening ecosystems and humans alike. Defaunation is experienced both locally (Hallmann et al. 2017), and globally (Dirzo et al. 2014), yet the loss of insect species may be highly underestimated (Purvis et al. 2000a; Dunn 2005). The decline in insect diversity as well as local population losses might have dramatic consequences for the provision of ecosystem functions and services (Balvanera et al. 2006; Ceballos et al. 2015), such as pollination, natural pest control or decomposition. Furthermore, above-ground species, which are (locally) rare and predominantly listed in red lists (cf. Ludwig et al. 2006), decrease with increasing land-use intensity, but have a positive effect on ecosystem functioning (e.g. Soliveres et al. 2016). To understand the mechanisms behind biodiversity loss and to improve conservation strategies, general knowledge of the drivers of species extinction processes has to improve. Species are affected by many extrinsic factors, such as habitat loss, fragmentation, habitat quality or climate change (Purvis et al. 2000b; Sala et al. 2000; Fahrig 2003), but their responses to these extrinsic factors are to a large extent dependent on their intrinsic characteristics. Species with similar trait values may show similar sensitivity to environmental change and have similar extinction risks, allowing for improved predictability of the effects of habitat alteration on species in general (see Moretti et al. 2017). Nevertheless, in comparison to a few charismatic groups, such as butterflies, dragonflies, damselflies or saproxylic beetles (Clausnitzer et al. 2009; Seibold et al. 2015; Essens et al. 2017), less is known about the drivers of species extinction probabilities in other insect groups.

Here, we focus on the extinction risk of a species-rich and functionally important group of insects, carabid beetles. Carabid beetles (Carabidae) are taxonomically and ecologically well-known (Homburg et al. 2014b) and a widely distributed taxon, occurring in decent numbers in almost every terrestrial ecosystem (Lövei and Sunderland 1996; Kotze et al. 2011), yet have also experienced a decrease in number (Brooks et al. 2012; Schmidt et al. 2016). These beetles perform important functional roles as predators of pest species and other invertebrates, or as granivores regulating weed seeds (Lövei and Sunderland 1996; Bohan et al. 2011), and provide an important opportunity to evaluate the effects of extirpation and extinction on ecosystems. Previous studies have discussed habitat specialization, body 
size and dispersal ability (hind wing morphology of carabid beetles) as potential predictors for species extinction risks in carabid beetles (Kotze and O'Hara 2003; Nolte et al. 2017). Additional drivers that may play a role in species vulnerability include distribution range size, diet, and reproductive period as well as trait combinations. Furthermore, since most carabid species exhibit preference for a specific habitat type, and anthropogenic effects act on many, if not all habitat types, habitat specialization per se can influence extinction probability (den Boer 1990).

Our study aimed to identify the relative importance of carabid beetle traits linked to extinction risk in order to better define and substantiate established ideas about extinction processes for insect species. For our analysis, we used the recently updated Red List status of carabid beetles in Germany as a proxy of the current species extinction risk. We selected a set of carabid beetle traits informed by earlier studies on the relationship of species traits and extinction risks (Kotze and O'Hara 2003; Henle et al. 2004; Terzopoulou et al. 2015) and made predictions on whether these traits would be positively or negatively associated with extinction risk (Table 1). Analyzing species traits on a large taxonomical and geographical scale will enable us to identify species groups that are more prone to extinction and to provide useful recommendations to counteract further insect loss which is currently under intensive public and scientific debate (Hallmann et al. 2017; Leather 2018).

\section{Methods}

\section{Carabid beetles and extinction risk}

The classification of extinction risk in the German National Red List of carabid beetles (Schmidt et al. 2016) follows the approach of Ludwig et al. (2006). This classification is mainly based on guidelines of the International Union for Conservation of Nature (IUCN), yet the German Red Lists does not fully follow the IUCN scheme for the classification of threatened species (Ludwig et al. 2005). In Germany, the size of the entire distribution range is not used in this classification. The three main classification criteria in Germany are i) the current species frequency (number of known populations or records in quadrants of topographic maps), ii) the historical development of the species frequency and iii) the 
expected development of the species frequency based on assumed trends of the habitats in which the given species occurs. This approach is applied to all national Red Lists of Germany (Ludwig et al. 2006).

Subspecies were merged to a single species and their highest stated Red List classification was used in order not to underestimate the actual extinction risk. A dataset of 566 carabid beetle species was used for the analyses. Of these species, 36\% (201 species) are threatened and listed in categories between 'vulnerable' to 'regionally extinct'. The categories 'indeterminate' and 'rare' list 63 species (11\%), the category 'near threatened' 53 species (10\%) and 'least concern' 245 species (43\%), and data are deficient for 4 species $(<1 \%$ ) (cf. Schmidt et al. 2016). For this study, we re-coded the Red List classification to an ordinal variable between zero for "least concern", and five for "regionally extinct" (see Online Resource Table A1).

\section{Species traits}

For the majority of German carabid beetle species we were able to compile a set of seven species traits and other characteristics (Table 1), reflecting basic aspects of ecophysiology and habitat selection (e.g. Thiele 1977). Information about body size and hind wing morphology (which are dispersal ability parameters), trophic level and breeding season were extracted from the carabids.org database (Homburg et al. 2014b) and complemented by a literature search and, if necessary, expert knowledge. Since the entire size of the distribution range of a species is not used in the determination of the Red List categories in Germany (Ludwig et al. 2006), we used it here as a distributional trait. As a proxy for the size of the entire distribution range we calculated the sum of the Palearctic countries' areas in which the given species has been recorded according to the Catalogue of Palearctic Coleoptera (Löbl and Smetana 2003). Habitat specialization is represented by the sum of habitats a species does not occur in, following the catalogue published by the Society for Applied Carabidology (GAC 2009). Thus, an increasing value indicates an increasing degree of habitat specialization. We classified habitat preference into eight categories, obtained for each species from the GAC catalogue. As main habitat preference of a given species the most frequently indicated habitat type was chosen (GAC 2009; Table 1). 


\section{Statistical analysis}

Species with missing trait information or with a Red List classification of 'indeterminate', 'rare' or 'data deficient' were excluded from the analysis. We also excluded species classified as eurytopic since they were all classified as "not threatened", which makes the applicability of the algorithms difficult; we performed a model including eurytopic species, but large standard errors were produced for the habitat preference of eurytopic species. The exclusion of eurytopic species did not influence our final results, as the calculated trait relationships were similar to the results we are presenting here. This resulted in the analysis of 464 carabid beetle species.

We fitted a proportional odds logistic regression model to evaluate the effect of species traits on extinction risk. All analyses were performed in R 3.4.1 (R Core Team 2017) using the package ordinal (Christensen 2015). According to Grafen (1989), phylogenetic relatedness between species can lead to non-independency between species in statistical tests. A molecular phylogeny, as described by phylogenetic trees, was not applicable, because for most species no DNA sequences are available. However, taxonomic hierarchies of carabid beetles are highly supported by current molecular phylogenetic trees (e.g. Ober and Maddison 2008). Therefore, to account for phylogenetic relatedness we used the function "phylo_clmm" provided by Seibold et al. (2015). This function uses speciesspecific intercepts to avoid inflation of the degrees of freedom caused by phylogentic relatedness. Species-specific intercepts were defined by a species-by-species taxonomic distance matrix based on taxonomical hierarchies according to the Catalogue of Palearctic Coleoptera (Löbl and Smetana 2003; Nolte et al. 2017). We performed five separate models. The general model included species of all habitat types $(\mathrm{n}=464$ species). Additionally, we conducted four separate models for species preferring the habitat types forest (59 species), open (172 species), riparian (97 species) and wetland (95 species) (see Table 2). For species preferring coastal, mountainous and special habitats, models were not applicable due to low species numbers. In all models, the ordered Red List classification was used as an ordinal response variable and species traits as predictor variables. To test for correlations between explanatory variables, categorical variables were transformed to continuous variables. None of the tested variables 
were highly correlated (Spearman's rank correlation, $\rho<0.70$; see Online Resource Table A2). The models contained all seven variables and the interaction between body size and hind wing morphology. We evaluated this interaction since body size and the trait values of carabid hind wing morphology might be interdependent (Homburg et al. 2013). We expect that small flightless species have restricted dispersal capacity, while large flightless species might be able to disperse well by walking larger distances. Additionally for species able to fly, large species may be able to disperse longer distances by active flight, but small species may also drift passively by wind (Chapman et al. 2005). To identify the best models we used backward selection based on Akaike's Information Criterion (AIC) until the AIC value stopped decreasing. Non-significant traits were left in the final models if they were involved in a significant interaction. To test for the effect of phylogeny on species extinction risk, we included phylogenetic taxonomy in all models, and compared these to models without phylogenetic taxonomy, using the conventional „clm“ function.

\section{Results}

The general model showed that extinction risk increased with increasing habitat specialization (Table 2,

Fig. 1). Furthermore, small distribution range sizes, predatory feeding behavior and the interaction of increasing body size and macroptery also significantly promoted species extinction probability. The analysis of habitat preference showed that species of forests and special habitats (e.g., caves, cellars, waste disposal sites) had a significantly lower risk of extinction than species of open habitats (Fig. 2). Species of mountainous and coastal habitats showed the highest extinction risk. As main effects, body size and hind wing morphology solely did not contribute significantly to extinction risk. Results of the model without phylogenetic information remained identical (data not shown).

Analyses of species associated with specific habitat types (forest, open, riparian, wetland) showed both congruencies and differences to the general model (Table 2, Fig. 1). All four models showed an increase in extinction risk with increasing habitat specialization. In most final models, small distribution range size and large body size were associated (significantly or with a trend) with high extinction probability. Neither of these traits were, however, included in the final model for forest 
species. Here the risk of extinction was most strongly affected by trophic level: predatory forest species showed a significantly higher risk of extinction than herbivorous forest species. Hind wing morphology and breeding season were only included in the final model of wetland carabid species. In wetland species, autumn breeders showed a significantly higher extinction risk than spring breeders and a nonsignificantly higher risk than winter breeders or species with a variable reproductive period. Brachypterous wetland species were also at higher risk of extinction than dimorphic species. Similar to the general model, phylogenetic information did not affect the results of these habitat specific models.

\section{Discussion}

Our general model including all species and the models including species of various habitat preference showed similar general results: increasing habitat specialization, decreasing distribution range size and larger body size coincided with a higher extinction risk of carabid beetle. The general model further showed that larger species that are macropterous had high extinction risks, and that species preferring mountainous, coastal and open habitat types were more at risk of extinction than forest species. However, forest species with a predatory feeding behavior, and wetland species that breed in the autumn, showed high extinction risks. Phylogenetic relatedness had no influence on how species traits predict carabid beetle extinction risk.

\section{Species traits as drivers of extinction risk}

Habitat specialization, distribution range size and body size were identified as important drivers of the extinction risk of carabid beetles. These traits also affect the extinction risks of other insect groups, such as beetles, dragonflies and butterflies (Koh et al. 2004; Jeppsson and Forslund 2014; Powney et al. 2015; Seibold et al. 2015).

Carabid beetle habitat specialization was the most important driver of extinction risk in all final models, except the forest habitat model where trophic level was more important (see Table 2). Indeed, Dunn (2005) has shown that narrow-habitat requirements are a more common driver of extinction in 
insects than in other animal taxa. Specialist species are particularly prone to extinction (Kotze and O'Hara 2003; Terzopoulou et al. 2015), due to their narrow niche and limited number of suitable habitats. During the last few decades, habitats of specialized species have decreased in size or have experienced severe disturbance, e.g., the fragmentation and disturbance due to land-use change, especially agricultural intensification and urban development, or wetland drainage and rectification measures on rivers (Hendrickx et al. 2007; Maltby et al. 2009). In addition, carabid beetle specialists show reluctance to move through unfavorable habitat, while generalists move more easily through the landscape as they can use various habitat types (Vermeulen 1994; Koivula et al. 2002). Functionally, a replacement of specialist species by broadly adapted generalists leads to the biotic and functional homogenization of biodiversity (McKinney and Lockwood 1999), with subsequent implications for ecosystem functioning (Clavel et al. 2011).

Small distribution range size, large body size and high trophic level were further predictors of extinction risk in our study. These three traits, as well as high habitat specialization, are generally associated with low population densities (Gaston 2003; Blackburn et al. 2009; see also Pearson et al. 2014). Small populations are more prone to become regionally extinct since they often lack adaptability to climate or landscape changes (Gaston and Fuller 2009), and are more vulnerable to stochastic events (Lande 1993; Robles and Ciudad 2012). Species with large distribution ranges can also exhibit low population densities due to habitat fragmentation, but generally have higher population densities (Brown 1984; Kotze et al. 2003; Gaston and Fuller 2009), and subsequently a lower risk of extinction since these populations are less likely to undergo simultaneous local extinction events. Importantly, the entire distribution range of a given species is often not a criterion used to assess the national threat status of species (Duelli 1994; Ludwig et al. 2006; Desender et al. 2008), but taking this trait into account might improve the Red List classification, at least for ground beetles.

Body size is considered a reliable predictor of extinction risk. For vertebrates, it is generally accepted that large bodied species are more prone to extinction than smaller species (Cardillo et al. 2005; Dirzo et al. 2014), a pattern also found in ground beetles (Kotze and O'Hara 2003; Brooks et al. 2012). Large species tend to have smaller population sizes but also lower reproduction rates and require large, 
unfragmented and stable habitats, more so than small species (Simberloff 1994; Matern et al. 2008). In congruence to Nolte et al. (2017), we did not find an effect of body size on the extinction risk of forest species. Compared to other habitats, forests show more stable environmental conditions and are expanding in area across Central Europe (e.g. Assmann 1999; FAO 2015), and forest species show less fluctuation in population densities (Günther and Assmann 2004). Instead, trophic level was the most important predictor of forest species extinction risks. Higher extinction risks of species at higher trophic level (predators) is in agreement with the higher trophic-rank hypothesis (Davies et al. 2000) but in contrast to the results of Nolte et al. (2017), who showed that herbivorous species are at lower occurrence ranks when studying community structure.

We expected hind wing morphology to be an important predictor of carabid beetle extinction risk, since it is closely related to a species' dispersal abilities (den Boer 1977). However, species with individuals capable of flight (macropterous and dimorphic species) showed a lower extinction risk than brachypterous species only in the general model and for wetland species. Dimorphic species in particular have been identified to be least threatened by fragmentation and species decline (Kotze and O'Hara 2003; Barbaro and van Halder 2009; Nolte et al. 2017). These species seem to benefit from a variable ecological strategy: during migration the number of individuals able to fly increases, which have a higher probability to successfully disperse and establish new populations, while under stable environmental conditions the number of flightless individuals increases, displaying higher fecundity and thus higher establishment abilities (den Boer et al. 1980; Langellotto et al. 2000; Zalewski et al. 2012); also known as the oogenesis-flight syndrome (see Desender 2000). Macropterous species generally have a higher dispersal power and consequently better colonization and recolonization possibilities than brachypterous species (den Boer 1990). However, this general assumption does not hold with an increase in body size. Our results show that macropterous species show significantly higher extinction risks with increasing body size than brachypterous species (Table 3). This may be a consequence of large natural-like habitats that became more fragmented in cultural landscapes (Finck et al. 2017). Several authors (e.g. den Boer 1990; Desender 1996; Günther and Assmann 2004) have shown that carabid species with welldeveloped wings and intensive flight activity exhibit stronger fluctuations in population sizes than species with low dispersal powers (especially brachypterous species). Due to strong population 
fluctuations, macropterous species need higher (re-) colonization to stabilize their occurrence. If the distance between suitable habitat patches is increasing, the dispersal power of even macropterous species may not be sufficient for colonization.

The breeding season of a species may influence survival rates, since the larval stage is the most sensitive in the life cycle of carabid beetles (Lövei and Sunderland 1996). For butterflies, developmental rate and phenology influenced Red List status significantly (WallisDeVries 2014). We found a significant influence of the trait breeding season only for species of wetland habitats. Anthropogenic changes in water regimes, changes of flood seasonality and magnitude as well as an increased frequency of winter floods (Petrow and Merz 2009) may increase the mortality rate of wetland species during winter and early spring. During this period, individuals of autumn breeders are in their sensitive larval stage, which is more negatively affected by long lasting inundations than the imagines of spring breeders (Lövei and Sunderland 1996).

\section{Habitat preference as a drivers of extinction risk}

Both habitat quality and quantity are crucial for the survival of a species. Over the last decades, landuse and habitat quantity have changed drastically (Fuchs et al. 2015), and the proportion of long-term endangered habitat types increased in Germany (Finck et al. 2017). Habitats are more intensively used or converted into agricultural and urban land, resulting in habitat loss and fragmentation, which are considered major threats to endangered species (e.g. Fahrig 2003; Groom et al. 2006; Rands et al. 2010; Hochkirch et al. 2016). Therefore, a strong and constant negative trend in habitat area is taken into account for species Red List classifications in Germany. Our results clearly show that species showing a strong preference for coastal, mountainous or open habitats face the highest risks of extinction and are in urgent need of protection, while most forest species are less threatened by extinction (see also Brooks et al. 2012). This result coincides with the respective decrease or increase in area covered by the given habitat types and the changes in habitat management in the anthropogenic landscape in Central Europe during the last decades. Especially coastal or open habitats, e.g. extensively grazed pastures or calcareous grasslands, face a dramatic decline in area (WallisDeVries et al. 2002), caused by 
intensification of land-use, especially pesticide and fertilizer use. Furthermore, mountainous habitats are subject to a drastic change in land-use; while accessibility dependent habitat abandonment and overgrazing of the given habitats are frequent, cold and moist habitats are decreasing due to their sensitivity to global warming (Dieker et al. 2011; Brooks et al. 2012). However, not all habitats are decreasing in cover; forests have increased in area across Europe in the last two centuries (Assmann 1999; FAO 2012, 2015) and showed the lowest proportion of threatened species. The man-made habitat increase might be the reason why studies show that species associated with forests are often increasing in recent decades (Brooks et al. 2012). But here especially the forest generalists might strongly benefit, while the forest specialists, on the other hand, depend more on habitat quality than on quantity. At least some of these habitat specialists are threatened (Nolte et al. 2017).

\section{Implications for nature conservation}

Based on the findings of this study, useful conservation management recommendations for the main target habitats and species can be provided (Barbaro and van Halder 2009). These recommendations may also be applied to other Central European countries and regions with a similar species pool, as this study covers most of the carabid beetle species found in Central Europe. We show that extinction risk can be identified from certain carabid beetle traits; in particular habitat specialization, distribution range size and body size. Species that exhibit specific values of these three traits in combination should be particularly the object of species' action plans and other activities that support these species. Even though only two carabid species occurring in Germany are listed in the annexes of the Natura 2000 Directive of the European Union (Council Directive 92/43/EEC, Annex II), both hold the trait values we identified leading to higher species extinction risks: (a) Carabus variolosus, a species with a longterm documentation of population decline (Breuning 1926) with a very narrow specialization to habitats of headwater brooks with slowly flowing streams (Matern et al. 2007). Moreover, this species has very small population sizes (Matern et al. 2008) and a small distribution range, as it is restricted to Central Europe and the Carpathian Basin (Turin et al. 2003). (b) Carabus menetriesi, a highly stenotopic species restricted to intact and constantly groundwater-influenced mesotrophic fens. The coincidence of small 
population sizes (Matern et al. 2008) and a small distribution range is obvious (Müller-Motzfeld 2005). Both species belong to the largest ground beetles in Germany and they show a small distribution range, with the more significant proportion located in Central Europe (Turin et al. 2003). Therefore, this region has an important responsibility for the worldwide preservation of both species (Gruttke et al. 2004).

These examples show that the sometimes criticized choice of invertebrate species (Cardoso 2012) listed by the Natura 2000 Directive of the European Union (Council Directive 92/43/EEC) covers carabid species that can be identified by other approaches as species of conservation concerns. Moreover, these species can act as umbrella species, as they are associated with other stenotopic carabid species that also show strong declines in Germany and in their entire distribution range (e.g. Chlaenius sulcicollis, Trautner and Rietze 2000). The preservation and regeneration of their habitats are a priority.

Second, we need to focus more on the conservation and restoration of habitat types that are decreasing in extent. The results of this study underline the importance of maintaining and restoring shrinking habitat types, especially mountainous, coastal and open habitats as well as wetlands. Without conservation efforts to protect these decreasing habitat types, we will continue to face massive insect species losses. The key to protect species of these habitat types is to reduce habitat artificialisation, increase habitat patch size (without decreasing other important habitat types), and to increase or restore habitat connectivity. If connectivity is not possible (e.g. for mountainous species), assisted migration may be an alternative under current changing environmental conditions, especially in the age of climate change (Homburg et al. 2014a; Seddon et al. 2014). 


\section{References}

Assmann T (1999) The ground beetle fauna of ancient and recent woodlands in the lowlands of northwest Germany (Coleoptera, Carabidae). Biodiversity and Conservation 8:1499-1517. https://doi.org/10.1023/A:1008974413376

Balvanera P, Pfisterer AB, Buchmann N, He J-S, Nakashizuka T, Raffaelli D, Schmid B (2006) Quantifying the evidence for biodiversity effects on ecosystem functioning and services. Ecol Lett 9:1146-1156. https://doi.org/10.1111/j.1461-0248.2006.00963.x

Barbaro L, van Halder I (2009) Linking bird, carabid beetle and butterfly life-history traits to habitat fragmentation in mosaic landscapes. Ecography 32:321-333. https://doi.org/10.1111/j.16000587.2008.05546.x

Blackburn TM, Lockwood JL, Cassey P (2009) Avian invasions: the ecology and evolution of exotic birds. Oxford University Press, New York

Bohan DA, Boursault A, Brooks DR, Petit S (2011) National-scale regulation of the weed seedbank by carabid predators. J Appl Ecol 48:888-898. https://doi.org/10.1111/j.1365-2664.2011.02008.x

Breuning S (1926) Ueber Carabus variolosus Fabr. Koleopterologische Rundschau 12:19-25

Brooks DR et al. (2012) Large carabid beetle declines in a United Kingdom monitoring network increases evidence for a widespread loss in insect biodiversity. J Appl Ecol 49:1009-1019. https://doi.org/10.1111/j.1365-2664.2012.02194.x

Brown JH (1984) On the relationship between abundance and distribution of species. American Naturalist:255-279

Cardillo M et al. (2005) Multiple Causes of High Extinction Risk in Large Mammal Species. Science 309:1239-1241. https://doi.org/10.1126/science.1116030

Cardoso P (2012) Habitats Directive species lists: urgent need of revision. Insect Conservation and Diversity 5:169-174. https://doi.org/10.1111/j.1752-4598.2011.00140.x

Ceballos G, Ehrlich PR, Barnosky AD, García A, Pringle RM, Palmer TM (2015) Accelerated modern human-induced species losses: Entering the sixth mass extinction. Science Advances 1: e1400253. https://doi.org/10.1126/sciadv.1400253 
Ceballos G, Ehrlich PR, Dirzo R (2017) Biological annihilation via the ongoing sixth mass extinction signaled by vertebrate population losses and declines. Proceedings of the National Academy of Sciences 114:E6089-E6096. https://doi.org/10.1073/pnas.1704949114

Chapman JW, Reynolds DR, Smith AD, Riley JR, Telfer MG, Woiwod IP (2005) Mass aerial migration in the carabid beetle Notiophilus biguttatus. Ecological Entomology 30:264-272. https://doi.org/10.1111/j.0307-6946.2005.00702.x

Christensen RHB (2015) Ordinal - Regression Models for Ordinal Data.

Clausnitzer V et al. (2009) Odonata enter the biodiversity crisis debate: The first global assessment of an insect group. Biol Conserv 142:1864-1869. https://doi.org/10.1016/j.biocon.2009.03.028

Clavel J, Julliard R, Devictor V (2011) Worldwide decline of specialist species: toward a global functional homogenization? Frontiers in Ecology and the Environment 9:222-228. https://doi.org/10.1890/080216

Council Directive 92/43/EEC of 21.05.1992 on the conservation of natural habitats and of wild fauna and flora. European Union,

Davies KF, Margules CR, Lawrence KF (2000) Which traits of species predict population declines in experimental forest fragments? Ecology 81:1450-1461. https://doi.org/10.1890/00129658(2000)081[1450:wtospp]2.0.co;2

den Boer P, van Huizen T, den Boer-Daanje W, Aukema B, den Bieman C (1980) Wing polymorphism and dimorphism in ground beetles as stages in an evolutionary process (Coleoptera: Carabidae). Entomologia Generalis 6:107-134

den Boer PJ (1968) Spreading of risk and stabilization of animal numbers. Acta biotheoretica 18:165194

den Boer PJ (1977) Dispersal power and survival: Carabids in a cultivated countryside. Veenman \& Zonen, Wageningen den Boer PJ (1990) Density limits and survival of local-populations in 64 carabid species with different powers of dispersal. J Evol Biol 3:19-48. https://doi.org/10.1046/j.14209101.1990.3010019.x

Desender K (1996) Diversity and dynamics of coastal dune carabids. Ann Zool Fenn 33:65-75 
Desender K (2000) Flight muscle development and dispersal in the life cycle of carabid beetles: patterns and processes. Bulletin de l'Institut Royal des Sciences Naturelles de Belgique, Entomologie 70:13-31

Desender K et al. (2008) Een nieuwe verspreidingsatlas van de loopkevers en zandloopkevers (Carabidae) in België. Instituut voor Natuur- en Bosonderzoek, Brussel

Dieker P, Drees C, Assmann T (2011) Two high-mountain burnet moth species (Lepidoptera, Zygaenidae) react differently to the global change drivers climate and land-use. Biol Conserv 144:2810-2818. https://doi.org/10.1016/j.biocon.2011.07.018

Dirzo R, Young HS, Galetti M, Ceballos G, Isaac NJB, Collen B (2014) Defaunation in the Anthropocene. Science 345:401-406. https://doi.org/10.1126/science.1251817

Duelli P (1994) Rote Liste der gefährdeten Tierarten der Schweiz vol Vollzug Umwelt VU-9008-D Bundesamt für Umwelt, Bern

Dunn RR (2005) Modern insect extinctions, the neglected majority. Conservation Biology 19:10301036. https://doi.org/10.1111/j.1523-1739.2005.00078.x

Essens T, van Langevelde F, Vos RA, Van Swaay CAM, WallisDeVries MF (2017) Ecological determinants of butterfly vulnerability across the European continent. J Insect Conserv 21:439-450. https://doi.org/10.1007/s10841-017-9972-4

Fahrig L (2003) Effects of habitat fragmentation on biodiversity. Annual Review of Ecology, Evolution, and Systematics 34:487-515. doi: 10.1146/annurev.ecolsys.34.011802.132419

FAO (2012) State of the World's Forests. Food and Agriculture Organization of the United Nations, Rome

FAO (2015) Global forest resources assessment 2015 Desk reference. Food and Agriculture Organization of the United Nations, Rome

Finck P, Heinze S, Raths U, Riecken U, Ssymank A (2017) Rote Liste der gefährdeten Biotoptypen Deutschlands: Dritte fortgeschriebene Fassung 2017. Naturschutz und Biologische Vielfalt $156: 637$ 
Fuchs R, Herold M, Verburg PH, Clevers JGPW, Eberle J (2015) Gross changes in reconstructions of historic land cover/use for Europe between 1900 and 2010. Glob Change Biol 21:299-313. https://doi.org/10.1111/gcb.12714

GAC (2009) Lebensraumpräferenzen der Laufkäfer Deutschlands - Wissensbasierter Katalog. Angewandte Carabidologie Supplement V:1-45

Gaston KJ (2003) The structure and dynamics of geographic ranges. Oxford University Press, New York

Gaston KJ, Fuller RA (2009) The sizes of species' geographic ranges. J Appl Ecol 46:1-9. https://doi.org/10.1111/j.1365-2664.2008.01596.x

Grafen A (1989) The Phylogenetic Regression. Philosophical Transactions of the Royal Society of London Series B, Biological Sciences 326:119-157

Groom MJ, Meffe GK, Carroll CR (2006) Principles of Conservation Biology. Oxford University Press, Sunderland, Massachusetts

Günther J, Assmann T (2004) Fluctuations of carabid populations inhabiting an ancient woodland (Coleoptera, Carabidae). Pedobiologia 48:159-164. https://doi.org/10.1016/j.pedobi.2003.11.002

Gruttke, H et al. (2004) Memorandum: Verantwortlichkeit Deutschlands für die weltweite Erhaltung von Arten. Naturschutz und biologische Vielfalt 8: 273-280

Hallmann CA et al. (2017) More than 75 percent decline over 27 years in total flying insect biomass in protected areas. Plos One 12:e0185809. https://doi.org/10.1371/journal.pone.0185809

Hendrickx F et al. (2007) How landscape structure, land-use intensity and habitat diversity affect components of total arthropod diversity in agricultural landscapes. J Appl Ecol 44:340-351. https://doi.org/10.1111/j.1365-2664.2006.01270.x

Henle K, Davies KF, Kleyer M, Margules C, Settele J (2004) Predictors of species sensitivity to fragmentation. Biodiversity and Conservation 13:207-251. https://doi.org/10.1023/B:BIOC.0000004319.91643.9e

Hochkirch A et al. (2016) European red list of Grasshoppers, Crickets and Bush-crickets. Publications Office of the European Union, Luxembourg. https://doi.org/10.2779/60944 
Homburg K, Brandt P, Drees C, Assmann T (2014a) Evolutionarily significant units in a flightless ground beetle show different climate niches and high extinction risk due to climate change. $\mathbf{J}$ Insect Conserv 18:781-790. https://doi.org/10.1007/s10841-014-9685-x

Homburg K, Homburg N, Schäfer F, Schuldt A, Assmann T (2014b) Carabids.org - a dynamic online database of ground beetle species traits (Coleoptera, Carabidae). Insect Conservation and Diversity 7:195-205. https://doi.org/10.1111/icad.12045

Koh LP, Sodhi NS, Brook BW (2004) Ecological Correlates of Extinction Proneness in Tropical Butterflies. Conservation Biology 18:1571-1578. https://doi:10.1111/j.15231739.2004.00468.x

Koivula M, Kukkonen J, Niemelä J (2002) Boreal carabid-beetle (Coleoptera, Carabidae) assemblages along the clear-cut originated succession gradient. Biodiversity and Conservation 11:12691288. https://doi.org/10.1023/A:1016018702894

Kotze DJ et al. (2011) Forty years of carabid beetle research in Europe - from taxonomy, biology, ecology and population studies to bioindication, habitat assessment and conservation. ZooKeys 100:55-148. https://doi.org/10.3897/zookeys.100.1523

Kotze DJ, Niemelä J, O'Hara RB, Turin H (2003) Testing abundance-range size relationships in European carabid beetles (Coleoptera, Carabidae). Ecography 26:553-566. https://doi.org/10.1034/j.1600-0587.2003.03488.x

Kotze DJ, O'Hara RB (2003) Species decline - but why? Explanations of carabid beetle (Coleoptera, Carabidae) declines in Europe. Oecologia 135:138-148. https://doi.org/10.1007/s00442-002$1174-3$

Lande R (1993) Risks of Population Extinction from Demographic and Environmental Stochasticity and Random Catastrophes. The American Naturalist 142:911-927. https://doi.org/10.1086/285580

Langellotto GA, Denno RF, Ott JR (2000) A trade-off between flight capability and reproduction in males of a wing-dimorphic insect. Ecology 81:865-875. https://doi.org/10.1890/00129658(2000)081[0865:ATOBFC]2.0.CO;2 
Leather SR (2018) "Ecological Armageddon" - more evidence for the drastic decline in insect numbers. Annals of Applied Biology 172:1-3. https://doi.org/10.1111/aab.12410

Löbl I, Smetana A (eds) (2003) Catalogue of Palaearctic Coleoptera Vol. 1: Archostemata, Myxophaga, Adephaga. Apollo Books, Stenstrup

Lövei GL, Sunderland KD (1996) Ecology and behavior of ground beetles (Coleoptera: Carabidae). Annual Review of Entomology 41:231-256

Ludwig G, Haupt H, Gruttke H, Binot-Hafke M (2005) Methodische Weiterentwicklung der Roten Listen gefährdeter Tiere, Pflanzen und Pilze in Deutschland - eine Übersicht. Natur und Landschaft 80:257-265

Ludwig G, Haupt H, Gruttke H, Binot-Hafke M (2006) Methodische Anleitung zur Erstellung Roter Listen gefährdeter Tiere, Pflanzen und Pilze. BfN-Skripten 191:1-97

Maltby E, Baker CJ, Barker T, Digby U, D.V. H, R.J. M, al. e (2009) Functional assessment of wetlands: Towards evaluation of ecosystem services. 1st Edition edn. Woodhead Publishing Limited, Cambridge

Matern A, Drees C, Kleinwachter M, Assmann T (2007) Habitat modelling for the conservation of the rare ground beetle species Carabus variolosus (Cololeoptera, Carabidae) in the riparian zones of headwaters. Biol Conserv 136:618-627. https://doi.org/10.1016/j.biocon.2007.01.006

Matern A, Drees C, Meyer H, Assmann T (2008) Population ecology of the rare carabid beetle Carabus variolosus (Coleoptera : Carabidae) in North-west Germany. J Insect Conserv 12:591-601. https://doi.org/10.1007/s10841-007-9096-3

McKinney ML, Lockwood JL (1999) Biotic homogenization: a few winners replacing many losers in the next mass extinction. Trends Ecol Evol 14:450-453. https://doi.org/10.1016/S0169$5347(99) 01679-1$

Moretti M et al. (2017) Handbook of protocols for standardized measurement of terrestrial invertebrate functional traits. Functional Ecology 31:558-567. https://doi.org/10.1111/1365-2435.12776 Müller-Motzfeld G (2005) Zur Taxonomie, Entdeckungsgeschichte und Verbreitung der „FFH-Art“ Carabus menetriesi Faldermann in Hummel, 1827. Angewandte Carabidologie Supplement 4:11-18 
Nolte D, Schuldt A, Gossner MM, Ulrich W, Assmann T (2017) Functional traits drive ground beetle community structures in Central European forests: Implications for conservation. Biol Conserv 213:5-12. https://doi.org/10.1016/j.biocon.2017.06.038

Pearson RG et al. (2014) Life history and spatial traits predict extinction risk due to climate change. Nat Clim Chang 4:217. https://doi.org/10.1038/nclimate2113

Petrow T, Merz B (2009) Trends in flood magnitude, frequency and seasonality in Germany in the period 1951-2002. Journal of Hydrology 371:129-141. https://doi.org/10.1016/j.jhydrol.2009.03.024

Powney GD, Cham SSA, Smallshire D, Isaac NJB (2015) Trait correlates of distribution trends in the Odonata of Britain and Ireland. PeerJ 3:e1410. https://doi.org/10.7717/peerj.1410

Purvis A, Gittleman JL, Cowlishaw G, Mace GM (2000a) Predicting extinction risk in declining species. P Roy Soc B-Biol Sci 267:1947-1952. https://doi.org/10.1098/rspb.2000.1234

Purvis A, Jones KE, Mace GM (2000b) Extinction. BioEssays 22:1123-1133. https://doi.org/10.1002/1521-1878(200012)22:12<1123::AID-BIES10>3.0.CO;2-C

R Core Team (2017) R: A language and environment for statistical computing. R Foundation for Statistical Computing, Vienna, Austria

Rands MRW et al. (2010) Biodiversity Conservation: Challenges Beyond 2010. Science 329:12981303. https://doi.org/10.1126/science.1189138

Robles H, Ciudad C (2012) Influence of Habitat Quality, Population Size, Patch Size, and Connectivity on Patch-Occupancy Dynamics of the Middle Spotted Woodpecker. Conservation Biology 26:284-293. https://doi.org/10.1111/j.1523-1739.2011.01816.x

Sala OE et al. (2000) Global Biodiversity Scenarios for the Year 2100. Science 287:1770-1774. https://doi.org/10.1126/science.287.5459.1770

Schmidt J, Trautner J, Müller-Motzfeld G (2016) Rote Liste und Gesamtartenliste der Laufkäfer (Coleoptera: Carabidae) Deutschlands. Naturschutz und Biologische Vielfalt 70 (4):139-204

Seddon PJ, Griffiths CJ, Soorae PS, Armstrong DP (2014) Reversing defaunation: Restoring species in a changing world. Science 345:406-412. https://doi.org/10.1126/science.1251818 
Seibold S, Brandl R, Buse J, Hothorn T, Schmidl J, Thorn S, Müller J (2015) Association of extinction risk of saproxylic beetles with ecological degradation of forests in Europe. Conservation Biology 29:382-390. https://doi.org/10.1111/cobi.12427

Simberloff D (1994) The ecology of extinction. Acta Palaeontologica Polonica 38:159-174

Soliveres S et al. (2016) Locally rare species influence grassland ecosystem multifunctionality. Philos T R Soc B 371. https://doi.org/10.1098/rstb.2015.0269

Terzopoulou S, Rigal F, Whittaker RJ, Borges PAV, Triantis KA (2015) Drivers of extinction: the case of Azorean beetles. Biology Letters 11. https://doi.org/10.1098/rsbl.2015.0273

Thiele H-U (1977) Carabid Beetles in Their Environments: A study on habitat selection by adaptations in physiology and behaviour. Springer Berlin

Trautner J, Rietze J (2000) Zur Verbreitung und Bestandssituation von Chlaenius sulcicollis (PAYKULL, 1798) in Europa und seinem Wiederfund in Deutschland. Angewandte Carabidologie 2:74-80

Turin H et al. (2003) Species accounts. In: Turin H, Penev L, Casale A (eds) The Genus Carabus in Europe: A Synthesis. Pensoft Publishers \& European Invertebrate Survey, Sofia, pp 151-284 Vermeulen R (1994) The effects of different vegetation structures on the dispersal of carabid beetles from poor sandy heaths and grasslands. In: Desender K, Dufrêne M, Loreau M, Luff ML, Maelfait J-P (eds) Carabid Beetles: Ecology and Evolution. Kluwer Academic Publishers, pp 387-392. https://doi.org/10.1007/978-94-017-0968-2

WallisDeVries MF (2014) Linking species assemblages to environmental change: Moving beyond the specialist-generalist dichotomy. Basic and Applied Ecology 15:279-287. https://doi.org/10.1016/j.baae.2014.05.001

WallisDeVries MF, Poschlod P, Willems JH (2002) Challenges for the conservation of calcareous grasslands in northwestern Europe: integrating the requirements of flora and fauna. Biol Conserv 104:265-273. https://doi.org/10.1016/S0006-3207(01)00191-4

Zalewski M, Sienkiewicz P, Kujawa K, Hajdamowicz I, Ulrich W (2012) Ground beetles on islands: on the effects of habitat and dispersal. Ann Zool Fenn 49:139-151. https://doi.org/10.5735/086.049.0302 


\section{Figure captions}

Fig. 1 Summary table of the results of the proportional odds linear mixed-effects models with speciesspecific random intercepts on the basis of taxonomic hierarchy to estimate the effects of species traits on the extinction risk of carabid beetle species in all habitat types across Germany, and for species of different habitat types. For categorical variables, factor levels are compared to carabid beetle species that are brachypterous, herbivorous and autumn breeders. Significant effects are shown with large circles ( $p<0.05$, circle diameter represents value of the standard estimate, - : trait character not present, $\bullet:$ trend effect $\mathrm{p}<0.1)$

Fig. 2 Relative extinction risk of species of different habitat types. Estimates of the variable habitat preference of the general model are used to compare species extinction risks. Letters above bars indicate significant differences between habitat groups (significant differences were based on calculating the general model varying species habitat identity represented by the model intercept). $\mathrm{F}=$ forest, $\mathrm{S}=$ special habitats, $\mathrm{R}=$ riparian, $\mathrm{W}=$ wetland, $\mathrm{O}=$ open, $\mathrm{C}=$ coastal, $\mathrm{M}=$ mountain. 


\section{Tables}

2 Table 1. Carabid beetle traits used in the analyses (adopted from GAC (2009); Homburg et al. (2014b)) and their assumed effects in terms of extinction risk (a 3 positive effect means an increase in extinction risks).

\begin{tabular}{|c|c|c|c|c|}
\hline Trait & Trait type & Trait value & Assumed trait effect & Literature \\
\hline Distribution range size & continuous & $\begin{array}{l}\text { Area of Palearctic countries in which the given } \\
\text { species recorded }\left(\mathrm{km}^{2}\right)\end{array}$ & $\begin{array}{l}\text { Negative. Increasing distribution range size leads } \\
\text { to lower extinction risk. }\end{array}$ & $\begin{array}{l}\text { Gaston and Fuller (2009); } \\
\text { Nolte et al. (2017) }\end{array}$ \\
\hline Habitat specialization & continuous & $\begin{array}{l}\text { Number of habitat types not occupied in Germany } \\
\text { (ranging from highly specialized (8) to extreme } \\
\text { generalist (1)) }\end{array}$ & $\begin{array}{l}\text { Positive. Extinction risk increases with habitat } \\
\text { specialization (fewer suitable habitats). }\end{array}$ & Kotze and O'Hara (2003) \\
\hline Habitat preference & nominal & $\begin{array}{l}\text { Coastal (C) } \\
\text { Eurytopic (E) } \\
\text { Forest (F) } \\
\text { Mountain (M) } \\
\text { Open (O) } \\
\text { Riparian (R) } \\
\text { Special habitats (S, such as skeletal soils or caves) } \\
\text { Wetland (W, does not include riparian habitats) }\end{array}$ & $\begin{array}{l}\text { Mixed. Species related to a habitat type that has } \\
\text { recently increased in Germany or Central Europe } \\
\text { have lower extinction risks than species of habitat } \\
\text { types that have decreased. }\end{array}$ & \\
\hline Body size & continuous & Mean body size $(\mathrm{cm})$ & $\begin{array}{l}\text { Positive. Larger body size leads to a higher } \\
\text { extinction risk. }\end{array}$ & $\begin{array}{l}\text { Kotze and O'Hara (2003); } \\
\text { Brooks et al. (2012); } \\
\text { Dirzo et al. (2014) }\end{array}$ \\
\hline Hind wing morphology & ordinal & $\begin{array}{l}\text { Brachypterous (= short winged, flightless) } \\
\text { Dimorphic (species with long and short winged } \\
\text { specimens) } \\
\text { Macropterous ( = fully winged, predominantly } \\
\text { flight-active) }\end{array}$ & $\begin{array}{l}\text { Mixed. Dimorphic species show the lowest } \\
\text { extinction risk due to their variable ecological } \\
\text { strategy, with high dispersal power and } \\
\text { establishment ability. Macropterous species benefit } \\
\text { from higher dispersal powers than brachypterous } \\
\text { species. }\end{array}$ & $\begin{array}{l}\text { Kotze and O'Hara (2003); } \\
\text { Nolte et al. (2017) }\end{array}$ \\
\hline Trophic level & nominal & $\begin{array}{l}\text { Herbivorous } \\
\text { Omnivorous } \\
\text { Predator }\end{array}$ & $\begin{array}{l}\text { Negative. A higher trophic level leads to a higher } \\
\text { extinction risk. }\end{array}$ & Davies et al. (2000) \\
\hline Breeding season & nominal & $\begin{array}{l}\text { Autumn breeder } \\
\text { Spring breeder } \\
\text { Variable breeding period (both spring and autumn } \\
\text { breeder) } \\
\text { Winter breeder }\end{array}$ & $\begin{array}{l}\text { Mixed. Species with a variable breeding season } \\
\text { have a lower extinction risk, while spring, autumn } \\
\text { and winter breeder show higher extinction risks. }\end{array}$ & $\begin{array}{l}\text { den Boer (1968); Nolte et } \\
\text { al. (2017) }\end{array}$ \\
\hline
\end{tabular}


Table 2. Results of the proportional odds linear mixed-effects models with species-specific random intercepts on the basis of taxonomic hierarchy, to estimate the effects of carabid beetle species traits on extinction risk in all habitat types across Germany and for species of different habitat types.

\begin{tabular}{|c|c|c|c|c|c|c|c|c|c|c|c|c|c|c|c|}
\hline \multirow[b]{2}{*}{ Variable } & \multicolumn{3}{|c|}{ All habitats $(n=464)$} & \multicolumn{3}{|c|}{ Forest $(n=59)$} & \multicolumn{3}{|c|}{ Open $(n=172)$} & \multicolumn{3}{|c|}{ Riparian $(n=97)$} & \multicolumn{3}{|c|}{ Wetland $(\mathrm{n}=95)$} \\
\hline & Estimate $^{\mathrm{b}}$ & SE & $\mathrm{z}$ & Estimate $^{\mathrm{b}}$ & SE & $\mathrm{z}$ & Estimate $^{\mathrm{b}}$ & SE & $\mathrm{z}$ & Estimate $^{\mathrm{b}}$ & SE & $\mathrm{z}$ & Estimate $^{\mathrm{b}}$ & SE & $\mathrm{z}$ \\
\hline Distribution range size & $-0.47 * * *$ & 0.11 & -4.18 & & & & $-0.60 * * *$ & 0.18 & -3.42 & $-0.42 *$ & 0.21 & -2.02 & -0.47 & 0.26 & -1.81 \\
\hline Habitat specialization & $1.39 * * *$ & 0.14 & 9.81 & $1.26 *$ & 0.54 & -2.33 & $1.39 * * *$ & 0.21 & -6.65 & $0.85 * * *$ & 0.23 & 3.75 & $2.11 * * *$ & 0.37 & -5.76 \\
\hline Body size & 0.14 & 0.23 & 0.60 & & & & 0.28 . & 0.15 & 1.89 & $0.54 * *$ & 0.20 & 2.71 & $0.90 * *$ & 0.28 & 3.23 \\
\hline \multicolumn{16}{|c|}{ Hind wing morphology (brachypterous) ${ }^{\mathrm{a}}$} \\
\hline Dimorphic & -0.68 & 0.57 & -1.19 & & & & & & & & & & -2.24 & 1.15 & -1.94 \\
\hline Macropterous & -0.17 & 0.53 & -0.32 & & & & & & & & & & -0.44 & 1.08 & -0.40 \\
\hline
\end{tabular}

Body size $\mathrm{x}$ hind wing morphology (body size $\mathrm{x}$ brachypterous) ${ }^{\mathrm{a}}$
Body size $x$ dimorphic
$\begin{array}{lll}0.35 & 0.34 & 1.03\end{array}$
Body size $\mathrm{x}$ macropterous
$0.63 * \quad 0.27 \quad 2.31$

Trophic Level (herbivorous)

$\begin{array}{lllllll}\text { Omnivorous } & 0.43 & 0.47 & 0.90 & \text { trait character not present } \\ \text { Predator } & 0.66 * & 0.31 & 2.11 & 14.76 * * * & 0.73 & 20.14\end{array}$

Breeding season (autumn) ${ }^{\mathrm{a}}$

Spring

Winter

Variable

Habitat preference (open) ${ }^{\mathrm{a}}$

$\begin{array}{llll}\text { Forest } & -3.04 * * * & 0.47 & -6.49 \\ \text { Wetland } & -0.27 & 0.29 & -0.91 \\ \text { Riparian } & -0.54 & 0.34 & -1.59 \\ \text { Coast } & 0.36 & 0.47 & 0.77 \\ \text { Mountain } & 0.97 & 0.88 & 1.10 \\ \text { Special habitat } & -1.75 * * & 0.66 & -2.67\end{array}$

$6 \quad{ }^{\text {a }}$ Factor levels to which the categorical variables are compared are given in brackets.

$7 \quad{ }^{\mathrm{b}}$ Significance levels: . $\mathrm{p}<0.1 ; * \mathrm{p}<0.05 ; * * \mathrm{p}<0.01 ; * * \mathrm{p}<0.001$ 
- Increasing extinction risk

- Decreasing extinction risk

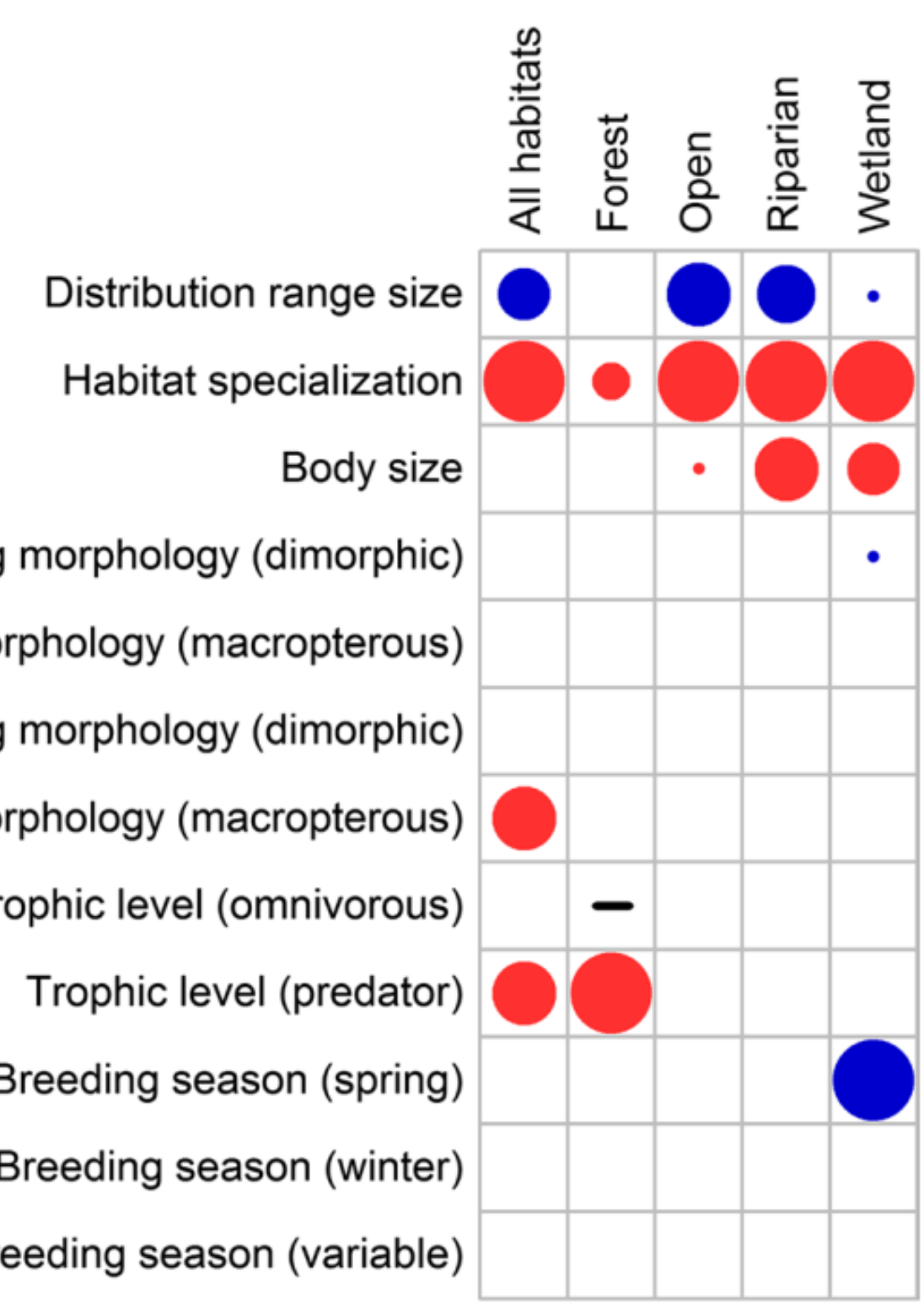




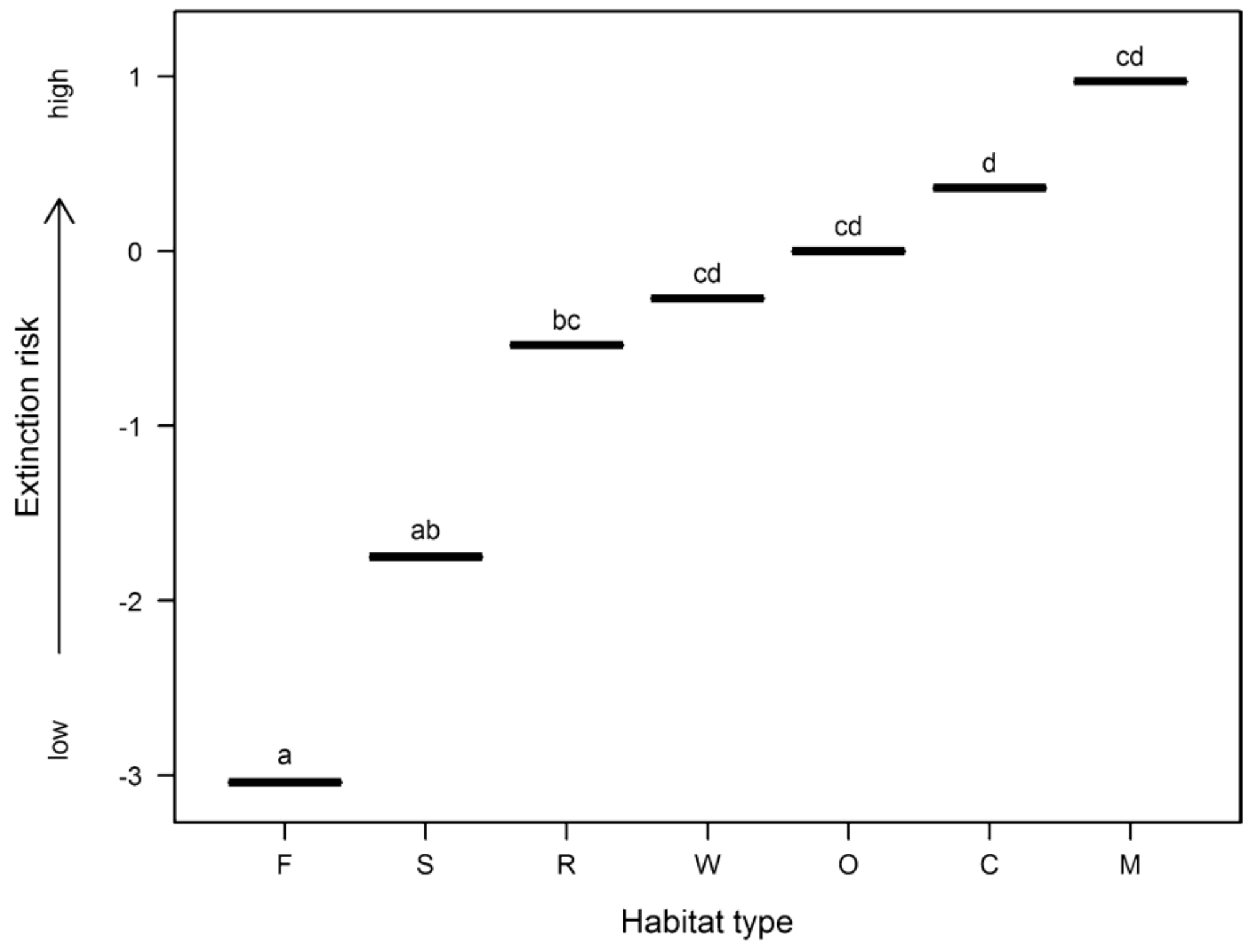


12 Appendix

13 Table A1. Categorization and nomenclature of extinction risks used by the IUCN and by Schmidt et al. (2016), including the ordinal code used in this paper.

\begin{tabular}{lll}
\hline Ordinal Red List code & IUCN categories & Categories in German \\
\hline 5 & RE: Regionally extinct & $0:$ Ausgestorben oder verschollen \\
4 & CR: Critically endangered & $1:$ Vom Aussterben bedroht \\
3 & EN: Endangered & $2:$ Stark gefährdet \\
2 & VU: Vulnerable & $3:$ Gefährdet \\
1 & NT: Near threatened & V: Vorwarnliste \\
0 & LC: Least concern & $*:$ Ungefährdet \\
\hline & I: Indeterminate & G: Gefährdung anzunehmen \\
& R: Rare & R: Extrem selten \\
& DD: Data deficient & D: Daten ungenügend \\
\hline
\end{tabular}

14

15

16 Table A2. Spearman rank correlations between six explanatory variables.

\begin{tabular}{|c|c|c|c|c|c|}
\hline & Habitat specialization & Body size & $\begin{array}{l}\text { Hind wing } \\
\text { morphology }\end{array}$ & Trophic level & Breeding seasor \\
\hline Habitat specialization & & 0.017 & -0.162 & -0.169 & 0.095 \\
\hline Hind wing morphology & & & & -0.225 & -0.210 \\
\hline Trophic level & & & & & -0.192 \\
\hline
\end{tabular}

17

18 